\title{
Modelling of Poverty Eradication in Kedungkandang District Malang City
}

\author{
Ismu Rini Dwi Ari \\ Department of Regional and Urban \\ Planning, Universitas Brawijaya, Jl. \\ MT. Haryono 167, Malang City, \\ East Java, Indonesia, 65145
}

\author{
Budi Soegiarto Waloejo \\ Department of Regional and Urban \\ Planning, Universitas Brawijaya, Jl. \\ MT. Haryono 167, Malang City, \\ East Java, Indonesia, 65145
}

\author{
Septiana Hariyani \\ Department of Regional and Urban \\ Planning, Universitas Brawijaya, Jl. \\ MT. Haryono 167, Malang City, East \\ Java, Indonesia, 65145
}

\begin{abstract}
Poverty as worldwide problems has multi dimensions, so that it is necessary a holistic approach to dealt with it. This research attempts to seek an appropriate strategy of poverty eradication by applying spatial regression analysis wherein value of water poverty index (WPI) put as dependent variable, travel time to senior high school and access to water physical attribute and rate of participation (RoP) and density social attributes put as independent variables with basic assumption that put it together development of physical and social aspects is a suitable approach on having better understanding of the poverty. This is an empirical research taken place at Kedungkandang District with unit of analysis of sub-district. Among 12 sub-districts general value of the WPI indicate 'high' poverty level, except 2 sub-districts with medium and medium low. Poverty in the district is mostly caused by use and environment components. Social network analysis with affiliation data of the head of households, measurement of RoP dan density indicate that social network in the community level through informal institutions form stronger social tie than their affiliation to formal institutions. Finally, classic test of regression model illustrates that both social and physical aspects give significant to the level of poverty. Strengthening social network through informal institutions and development of better access to safe water might decrease poverty level of the community.
\end{abstract}

Keywords- Components of water poverty, rate of participation, density, spatial regression analysis

\section{INTRODUCTION}

Poverty is a multidimensional and multisectoral problem that occurs in many countries in the world. The goal of poverty alleviation in 2030 has been mentioned in the SDGs goals. Poverty can be seen from several perspectives, so poverty also cannot be solved from one side only. In developing countries, the problem of low income (people living under the poverty line) is the main problem in economic development. As a result of this problem, many countries especially Indonesia has been created specifics strategies to increase national income and poverty reduction [1].

Poverty in Indonesia is a problem that has to be seriously tackle in order to reduce the negative impacts of its poverty. Determination of the poor population can be categorized into six indicators such as livable homes, access to clean water and sanitation, income, ownership of assets, frequency of food and quality of food nutrition [2]. The number of poor populations in Indonesia (2019) was about $9.41 \%$ and decreased by $0.41 \%$ in 2018. In general, residents in urban areas might say that they have better condition than the residents in rural areas, since the percentage of poor residents in urban areas are less than the rural areas, $6.695 \%$ and $12.85 \%$, respectively. In addition, the poverty line in Indonesia was 425,250 IDR/capita/month [3].

One problem of poverty is the limitation in basic needs, especially clean water needed. Water poverty or water crisis is also one indicator of poverty causes that are classified by the World Bank (2010). Water poverty is limitation access of water needs for everyday community needs. People are classified to be in water crisis if the availability of water is not sufficient for their basic needs. Lack of ability to water access is one of problem of poverty in Indonesia. The problem of water poverty occurs due to population growth rapidly, so water use competition is getting severe [4]. Water Poverty Index (WPI) is a method that used to measure poverty in clean water covering five components, namely resources, access, capacity, use and the environment. The WPI can be used for the government to build a strategy development in order to decrease poverty level in the scope community through clean water sector approach [5].

Sustainable Development Goals (SDGs), particularly in the pillar number $6^{\text {th }}$, it is noted that to solve problem of water poverty that have target of ensuring the community in achieving universal access to clean water and sanitation in 2030. There are four ways to answer the goals or target of the SDGs. The first target is to achieve universal and equitable access to safe and affordable drinking water for all. The second is to improve the water quality by reducing pollution reduce the rate of water loss, and minimizing the release of hazardous and chemicals materials, reducing half the proportion of untreated wastewater, and increasing water recycling, and reusing safe recycled goods globally. Thirdly, to improve the efficiency of water use in all sectors, and ensure sustainable use and supply of fresh water to overcome water scarcity, and reduce the number of people suffering from water scarcity. Then, the last is implemented integrated water resources management in all levels, including appropriate cross-border cooperation [6]. Households that have better community connection by participating in institution, have ability to manage their problem [7]. Good social interaction among society can assume that can be 
influence each other and exchange of information and knowledge $[8,9,10]$.

Data from the Central Bureau of Statistic (2019) shows that the poverty depth index in Malang City from 2018 to 2019 was unchanged at 0.55 . The poverty depth index measured by average from gap of outcome each poor population and the poverty line. Coverage of piped water services with access from the Local Water Company (PDAM) Malang City is about $96.24 \%$ of the total population of Malang City [11]. Kedungkandang District is one among five of the districts in Malang City, which located adjacent to area of Malang City. The number of poor people in the District is about 1307 households [12]. Amongst all sub-districts in the District, in one side Kota Lama has the highest number of poor households, meanwhile in the other side, Arjowinangun has the lowest one, 816 and 167 households, respectively. Hence, main aim of the research is to seek better understanding of the significant attributes of the poverty with basic assumption that appropriate poverty eradication strategy needs to put it together development of both physical and social aspects.

\section{DATA AND METHOD}

\section{A. Population and Sampling}

Research area is conducted in Kedungkandang District, Malang City whereby unit of analysis is divided into poor and non-poor households. The sample size is distributed to 551 households of the total 38463 households (1.4\%), spread across in 12 sub-districts proportionately. Data is collected through primary and secondary survey conducted from April June 2019.

TABLE I. DATA NEEDS

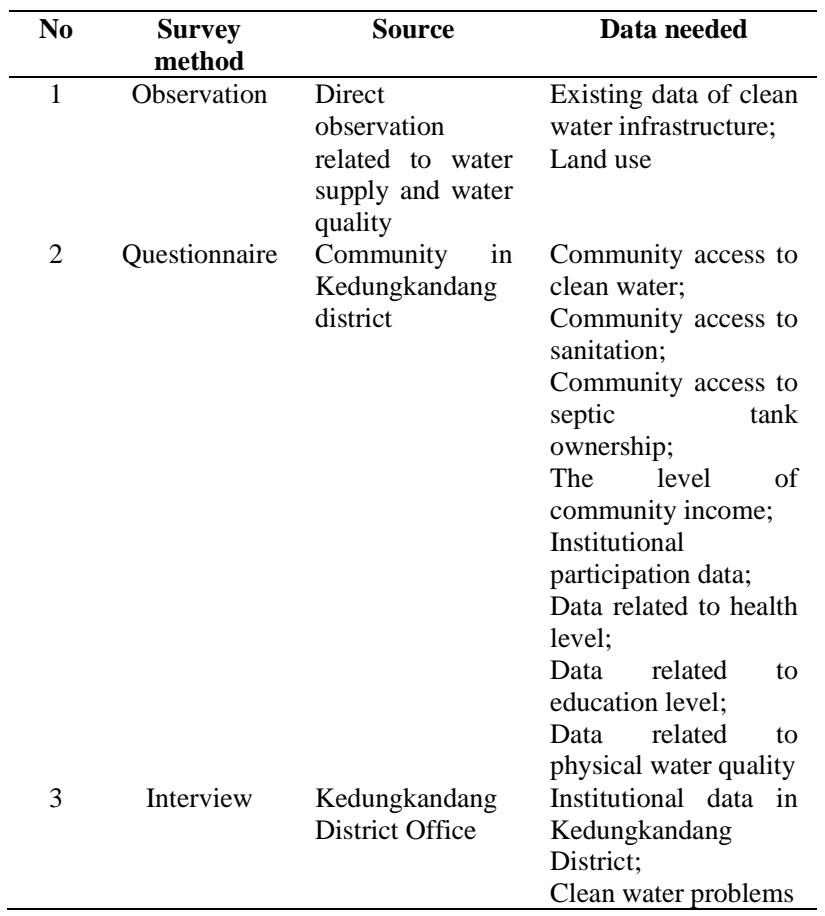

\section{B. Water Poverty Index (WPI)}

The WPI is a method to identify water poverty and measure the level of community welfare that is implemented in the level district. It has value in range between 0 to 100 consist of 5 components, namely i) availability of Resources (R), ii) Access (A), iii) Capacity (C), iv) Use (U) and v) Environment (E). The weight is applied to each component of the WPI structure, for the related region. The formula is the sum of weight times the value of each component, then divided by the sum of weights $[13,14,15,16]$.

\section{1) Resources (R)}

Resources (R) is the physical availability of surface and ground water. Water availability is calculated using the annual water availability approach per capita. Annual water availability is adopted from calculation of the water availability index which can be searched by sum of ground water availability and piped water then divided by the number of populations [16].

\section{2) Access (A)}

Access (A) consists of three components that are counted, namely i) access to clean water (percentage of households who have been served by safe water), iii) access to clean sanitation (percentage of households who have bathroom or latrine), and iii) access to septictank (septictank individual ownership). Value of the component of Access (A) is calculating by average value of access to clean water, access to sanitation and access to septictank ownership [16]. Access to clean water is the percentage of the population served by the clean water pipeline by PDAM (Local Water Company). Access to sanitation ownership is a percentage of the population who have private latrine at home, while access to septic tank ownership is a percentage of the population who have private or communal septictank.

\section{3) Capacity (C)}

Component of capacity (C) consists of three components, covering i) level of public education, ii) level of public health and iii) the level of income distribution. The level of income distribution is calculated using Gini index.

\section{4) Use (U)}

Component of use (U) has two indicators, namely i) domestic, and ii) agricultural water use. Use of domestic water has a range that commonly used between $0-320$ liters/capita/day. Use of water for agriculture is calculated by the percentage of land that uses irrigation then divided by total area of cultivation.

\section{5) Environmental (E)}

Environmental (E) component has two indicators including water quality and open space area. The measurement of water quality includes piped water quality (PDAM - Local Company Drinking Water /HIPPAM Community Drinking Water Users Association) and groundwater quality (well). For the open space area or vegetation cover is a percentage of green space area. The calculation of water quality in this research uses a laboratory test, then it is analyzed using STORET method that has 5 parameters consist of $\mathrm{PH}$, DO, turbidity, electrical conductivity, and salinity.

The WPI value of each component is multiplied by the weight value. In this research using agricultural, industrial and 
social weights that classified from Sullivan et al (2002) based on research area. The weight values are $\mathrm{R}=1, \mathrm{~A}=2, \mathrm{C}=2, \mathrm{U}$ $=3, \mathrm{E}=1$. The final value of WPI classified into 5 level of poverty indexes: 0 - 47.9 (severe), 48.0 - 55.9 (high), 56.0 61.9 (medium), 62.0 - 67.9 (medium low), 68.0 - 100 (low poverty index) [17]. Meaning that the higher WPI index, the lower poverty level of a certain area.

\section{Social Network Analysis}

Social Network Analysis (SNA) is an approach method to scrutinize relationship between actors and events as one set of affiliation data $[11,16]$ that is run with a special software package for analysis of social network data, namely UNICET 6.666 for Windows. In addition, there is a special type of input data that is used for the SNA - namely affiliation data, that is a set of affiliation data that is developed form jointness of each actor/respondent into one or more institutions. There are two indexes that is used in the research to depict social tie among residents in the research area, explicitly rate of participant (RoP) and density [9]. Result of the RoP describes level of participation of the community that is obtained from the average amount of community participation into a certain number of present institutions of the community area based on the formula that is designed by Wasserman and Faust [18]. The density is calculated to find out how dense relationship among community members in the research area, meaning that the higher value of density might illustrate the more solid or higher tie between actors within the research area, that the formula is developed by Scott, Wasserman and Faust [18]. Then, the results of both indexes are divided into 3 classes high, medium and low classifications [9].

\section{RESULT AND DISCUSSION}

\section{A. Water Poverty Index}

1) Resource $(R)$

Based on observations survey of water sources, Kedungkandang district have 2 water resource from ground water, and piped water connection. Access to water from groundwater comes from community private wells, meanwhile access to ccommunity piped water supplied by the HIPPAM (Community Drinking Water Users Association). In general, access to piped water connection in Kedungkandang District is served by both the PDAM - Local Company Drinking Water and HIPPAM - Community Drinking Water Users Association, except Cemorokandang sub-district as the only one sub-district without access to piped water from the $P D A M$. The Water Resources (R) value calculated by water contributions (water availability index) comparing with percentage of water estimation. The following Table II describe results of the component Resource (R).

TABLE II.
\begin{tabular}{|l|l|l|l|l|l|l|}
\hline \multicolumn{7}{|c|}{ WATER POVERTY INDEX RESOURCE } \\
\hline Sub-district & A & B & C & D & E & F \\
\hline Arjowinangu & 0 & 10 & 100 & 16000 & 100 & 100 \\
\hline Tlogowaru & 0 & 10 & 100 & 16000 & 100 & 100 \\
\hline Wonokoyo & 0 & 10 & 100 & 16000 & 100 & 100 \\
\hline Bumiayu & 0 & 10 & 100 & 16000 & 100 & 100 \\
\hline Buring & 0 & 10 & 100 & 16000 & 100 & 100 \\
\hline Mergosono & 0 & 10 & 100 & 16000 & 100 & 100 \\
\hline Kotalama & 0 & 10 & 100 & 16000 & 100 & 100 \\
\hline Kedungkandan & 0 & 10 & 100 & 16000 & 100 & 100 \\
\hline Sawojajar & 0 & 15 & 100 & 16000 & 100 & 100 \\
\hline Madyopuro & 0 & 8 & 100 & 16000 & 100 & 100 \\
\hline
\end{tabular}

\begin{tabular}{|l|l|l|l|l|l|l|}
\hline Lesanpuro & 0 & 10 & 100 & 16000 & 100 & 100 \\
\hline Cemorokandang & 0 & 10 & 100 & 3500 & 100 & 100 \\
\hline
\end{tabular}
*A : Surface water availability

*A : Surface water availability

B : Ground water availability

$\mathrm{C}$ : Ground water value

D : Piped water availability (m3/capita/year)

E : Piped water vaue

F : R Value

Table III shows that the resource variable can be calculated by the value of water availability which is divided into surface water availability, ground water availability and piped water availability. For domestic use, community in Kedungkandang District has water source from ground water through the building of private well $(8-15$ meters depth), the PDAM services, as well as the HIPPAM (Community Drinking Water Users Association) services. The availability of piped water is calculated from the availability of water in the reservoir. Availability of water for both poor and non-poor households within one village is considered to have similar value. The availability of surface water has value of 0 because in the research area, there is no household that uses surface water (lake water or river water) for their daily needs.

\section{2) Access (A)}

All households in Kedungkandang District are served by clean water for their daily needs, but some people still use dug well as their access to clean water. Access to clean water is declared good (not poor) if every house uses piped water from the PDAM (Local Company Drinking Water) or the HIPPAM (Community Drinking Water Users Association). Access to healthy waste is measured from the ownership of each household's septictank, because with the existence of a septictank it indicates that household have effort to treat domestic waste water. Primary data show that not all houses have their individual (private) septictank, since some houses that have their own latrines, however the waste water goes to 1 communal septic tank in a certain public area. The following three tables - Table III, IV and V describe the value of component access (A) that is divided into combined of poor and non-poor households, poor and non-poor households.

TABLE III. WATER POVERTY INDEX ACCESS COMBINED

\begin{tabular}{|l|l|l|l|l|l|}
\hline \multicolumn{6}{|c|}{ Access (A) } \\
\hline No & Sub-district & $\begin{array}{l}\text { Water } \\
\text { access }\end{array}$ & $\begin{array}{l}\text { Sanitation } \\
\text { access }\end{array}$ & $\begin{array}{l}\text { Septictank } \\
\text { access }\end{array}$ & $\begin{array}{l}\text { A } \\
\text { Value }\end{array}$ \\
\hline 1 & Arjowinangu & $30 \%$ & $100 \%$ & $100 \%$ & 77 \\
\hline 2 & Tlogowaru & $32 \%$ & $100 \%$ & $100 \%$ & 77 \\
\hline 3 & Wonokoyo & $33 \%$ & $100 \%$ & $94 \%$ & 76 \\
\hline 4 & Bumiayu & $24 \%$ & $100 \%$ & $100 \%$ & 75 \\
\hline 5 & Buring & $36 \%$ & $100 \%$ & $100 \%$ & 79 \\
\hline 6 & Mergosono & $83 \%$ & $100 \%$ & $100 \%$ & 94 \\
\hline 7 & Kotalama & $79 \%$ & $100 \%$ & $58 \%$ & 79 \\
\hline 8 & Kedungkandan & $83 \%$ & $100 \%$ & $100 \%$ & 94 \\
\hline 9 & Sawojajar & $92 \%$ & $100 \%$ & $100 \%$ & 97 \\
\hline 10 & Madyopuro & $35 \%$ & $100 \%$ & $100 \%$ & 78 \\
\hline 11 & Lesanpuro & $52 \%$ & $100 \%$ & $100 \%$ & 84 \\
\hline 12 & Cemorokandang & $0 \%$ & $100 \%$ & $100 \%$ & 67 \\
\hline
\end{tabular}

TABLE IV. WATER POVERTY INDEX ACCESS (A) POOR HOUSEHOLD

\begin{tabular}{|l|l|l|l|l|l|}
\hline \multicolumn{5}{|c|}{ Access (A) } \\
\hline No & Sub-district & $\begin{array}{c}\text { Water } \\
\text { access }\end{array}$ & $\begin{array}{c}\text { Sanitation } \\
\text { access }\end{array}$ & $\begin{array}{c}\text { Septictank } \\
\text { access }\end{array}$ & $\begin{array}{c}\text { A } \\
\text { Value }\end{array}$ \\
\hline 1 & Arjowinangu & $31 \%$ & $100 \%$ & $100 \%$ & 77,00 \\
\hline 2 & Tlogowaru & $38 \%$ & $100 \%$ & $100 \%$ & 79,33 \\
\hline 3 & Wonokoyo & $31 \%$ & $100 \%$ & $80 \%$ & 70,33 \\
\hline 4 & Bumiayu & $24 \%$ & $100 \%$ & $100 \%$ & 74,67 \\
\hline 5 & Buring & $27 \%$ & $100 \%$ & $100 \%$ & 75,67 \\
\hline 6 & Mergosono & $71 \%$ & $100 \%$ & $100 \%$ & 90,20 \\
\hline 7 & Kotalama & $75 \%$ & $100 \%$ & $57 \%$ & 77,17 \\
\hline
\end{tabular}




\begin{tabular}{|l|l|l|l|l|l|}
\hline 8 & Kedungkandan & $82 \%$ & $100 \%$ & $100 \%$ & 94,00 \\
\hline 9 & Sawojajar & $81 \%$ & $100 \%$ & $100 \%$ & 93,65 \\
\hline 10 & Madyopuro & $27 \%$ & $100 \%$ & $100 \%$ & 75,67 \\
\hline 11 & Lesanpuro & $53 \%$ & $100 \%$ & $100 \%$ & 84,33 \\
\hline 12 & Cemorokandang & $0 \%$ & $100 \%$ & $100 \%$ & 66,67 \\
\hline
\end{tabular}

TABLE V. WATER POVERTY INDEX ACCESS (A) NONPOOR HOUSEHOLD

\begin{tabular}{|l|l|l|l|l|l|}
\hline \multicolumn{7}{|c|}{ Access (A) } \\
\hline No & Sub-district & $\begin{array}{l}\text { Water } \\
\text { access }\end{array}$ & $\begin{array}{l}\text { Sanitation } \\
\text { access }\end{array}$ & $\begin{array}{l}\text { Septictank } \\
\text { access }\end{array}$ & $\begin{array}{l}\text { A } \\
\text { Value }\end{array}$ \\
\hline 1 & Arjowinangu & $32 \%$ & $100 \%$ & $100 \%$ & 77,33 \\
\hline 2 & Tlogowaru & $42 \%$ & $100 \%$ & $100 \%$ & 80,67 \\
\hline 3 & Wonokoyo & $30 \%$ & $100 \%$ & $100 \%$ & 76,67 \\
\hline 4 & Bumiayu & $23 \%$ & $100 \%$ & $100 \%$ & 74,33 \\
\hline 5 & Buring & $32 \%$ & $100 \%$ & $100 \%$ & 77,33 \\
\hline 6 & Mergosono & $83 \%$ & $100 \%$ & $100 \%$ & 94,33 \\
\hline 7 & Kotalama & $72 \%$ & $100 \%$ & $59 \%$ & 76,85 \\
\hline 8 & Kedungkandan & $81 \%$ & $100 \%$ & $100 \%$ & 93,67 \\
\hline 9 & Sawojajar & $91 \%$ & $100 \%$ & $100 \%$ & 97,00 \\
\hline 10 & Madyopuro & $31 \%$ & $100 \%$ & $100 \%$ & 77,00 \\
\hline 11 & Lesanpuro & $52 \%$ & $100 \%$ & $100 \%$ & 84,00 \\
\hline 12 & Cemorokandang & $0 \%$ & $100 \%$ & $100 \%$ & 66,67 \\
\hline
\end{tabular}

Table III illustrates general access of water in good value $(67$ - 97). Table IV and V indicate that access to water for non-poor households have better access than the poor one, due to their limited access to piped water connection and waste system. Cemorokandang sub-district has $0 \%$ of water access because there is no piped access from the PDAM (Local Company Drinking Water) nor from the HIPPAM (Community Drinking Water Users Association). Households in Kotalama sub-district have low access to septictank, due to their location of houses in the high dense areas as well as along riverbanks.

\section{3) Capacity (C)}

One of the WPI analysis components is the capacity which includes level of health, education level, and expenditure distribution which is analyzed using the Gini index. Results of the Gini index calculation for each sub-district is based on their income level. The level of education is calculated from the number of people who have a minimum education (Senior High School), regarding the 2015 Minister of Education and Culture Regulation that compulsory education for Indonesian citizen is 12 years. All respondents in Kedungkandang District have a good level of health. The following Table VI displays value of the WPI of Capacity (C) component in the district as the average value of health level, education level, and Gini index.

TABLE VI. WATER POVERTY INDEX CAPACITY COMBINED

\begin{tabular}{|l|l|l|l|l|}
\hline \multicolumn{7}{|c|}{ Capacity (C) } \\
\hline Subdistrict & Health & Education & Gini & WPI \\
\hline Arjowinangu & $100,0 \%$ & $80,00 \%$ & 0,26 & 84,7 \\
\hline Tlogowaru & $100,0 \%$ & $68,00 \%$ & 0,15 & 84,3 \\
\hline Wonokoyo & $98,0 \%$ & $66,00 \%$ & 0,24 & 80,0 \\
\hline Bumiayu & $100,0 \%$ & $86,00 \%$ & 0,27 & 86,3 \\
\hline Buring & $100,0 \%$ & $83,33 \%$ & 0,23 & 86,8 \\
\hline Mergosono & $100,0 \%$ & $70,00 \%$ & 0,30 & 80,0 \\
\hline Kotalama & $100,0 \%$ & $70,00 \%$ & 0,24 & 82,0 \\
\hline Kedungkandan & $97,0 \%$ & $74,00 \%$ & 0,31 & 80,0 \\
\hline Sawojajar & $100,0 \%$ & $70,00 \%$ & 0,22 & 82,7 \\
\hline Madyopuro & $100,0 \%$ & $75,86 \%$ & 0,32 & 81,3 \\
\hline Lesanpuro & $100,0 \%$ & $69,64 \%$ & 0,21 & 82,9 \\
\hline Cemorokandang & $100 \%$ & $72,97 \%$ & 0,30 & 81,0 \\
\hline
\end{tabular}

TABLE VII. WATER POVERTY INDEX CAPACITY (C) POOR HOUSEHOLD

\begin{tabular}{|l|l|l|l|l|}
\hline \multicolumn{5}{|c|}{ Capacity (C) } \\
\hline \multicolumn{1}{|c|}{ Subdistrict } & Health & Education & Gini & WPI \\
\hline Arjowinangu & $100.0 \%$ & $56 \%$ & 0.26 & 76.5 \\
\hline Tlogowaru & $100.0 \%$ & $57 \%$ & 0.15 & 80.7 \\
\hline Wonokoyo & $100.0 \%$ & $40 \%$ & 0.24 & 72.0 \\
\hline Bumiayu & $100.0 \%$ & $69 \%$ & 0.27 & 80.7 \\
\hline Buring & $100.0 \%$ & $60 \%$ & 0.23 & 79.0 \\
\hline Mergosono & $100.0 \%$ & $47 \%$ & 0.30 & 72.4 \\
\hline Kotalama & $100.0 \%$ & $48 \%$ & 0.24 & 74.6 \\
\hline Kedungkandan & $88.9 \%$ & $56 \%$ & 0.31 & 71.1 \\
\hline Sawojajar & $100.0 \%$ & $52 \%$ & 0.22 & 76.8 \\
\hline Madyopuro & $100.0 \%$ & $56 \%$ & 0.32 & 74.8 \\
\hline Lesanpuro & $100.0 \%$ & $53 \%$ & 0.21 & 77.4 \\
\hline Cemorokandang & $100 \%$ & $25 \%$ & 0.30 & 65.0 \\
\hline
\end{tabular}

TABLE VIII. WATER POVERTY INDEX CAPACITY (C) NONPOOR HOUSEHOLD

\begin{tabular}{|l|l|l|l|l|}
\hline \multicolumn{7}{|c|}{ Capacity (C) } \\
\hline \multicolumn{1}{|c|}{ Subdistrict } & Health & Education & Gini & WPI \\
\hline Arjowinangu & $100.0 \%$ & $80.95 \%$ & 0.26 & 85.0 \\
\hline Tlogowaru & $100.0 \%$ & $75.00 \%$ & 0.15 & 86.7 \\
\hline Wonokoyo & $92.3 \%$ & $76.92 \%$ & 0.24 & 81.7 \\
\hline Bumiayu & $100.0 \%$ & $91.67 \%$ & 0.27 & 88.2 \\
\hline Buring & $100.0 \%$ & $92.31 \%$ & 0.23 & 89.8 \\
\hline Mergosono & $100.0 \%$ & $80.00 \%$ & 0.30 & 83.3 \\
\hline Kotalama & $100.0 \%$ & $77.61 \%$ & 0.24 & 84.5 \\
\hline Kedungkandan & $100.0 \%$ & $81.82 \%$ & 0.31 & 83.6 \\
\hline Sawojajar & $100.0 \%$ & $75.93 \%$ & 0.22 & 84.6 \\
\hline Madyopuro & $100.0 \%$ & $83.33 \%$ & 0.32 & 83.8 \\
\hline Lesanpuro & $100.0 \%$ & $75.61 \%$ & 0.21 & 84.9 \\
\hline Cemorokandang & $100 \%$ & $86.21 \%$ & 0.3 & 85.4 \\
\hline
\end{tabular}

The level of health in poor households tends to be the same as non-poor households, which means that there are residents in poor and non-poor households who are still sick due to clean water problems such as diarrhea. Calculating the level of education, poor households, the value of education is lower than the non-poor households, which means that members of the poor households who did not graduated from Senior High School are higher than the non-poor households. Then, for the calculation of Gini index, the poor and non-poor households are considered having similar value, because the value of the Gini index is the index value for 1 region. The Gini index value is then equated to the WPI value by means of the 1-gini index value multiplied by 100 .

4) Use (U)

Water use for people is the comparison between the standard water supply needs and domestic water needs. Water use for agriculture is comparison between irrigation area and total irrigation + non irrigation area. Not all villages have wet agricultural land and use irrigation water channels. There are areas that do not have agricultural land area due to limited data obtained.

TABLE IX. WATER POVERTY INDEX USE

\begin{tabular}{|l|l|l|l|l|l|l|l|}
\hline Subdistrict & a & b & c & d & e & f & g \\
\hline Arjowinangu & 0.70 & 70 & 16.60 & 159.6 & $10 \%$ & 10 & 40 \\
\hline Tlogowaru & 0.74 & 74 & 70.35 & 146.3 & $48 \%$ & 48 & 61 \\
\hline Wonokoyo & 0.74 & 74 & 81.70 & 472.5 & $17 \%$ & 17 & 46 \\
\hline Bumiayu & 0.74 & 74 & 26.08 & 186.7 & $14 \%$ & 14 & 44 \\
\hline Buring & 0.74 & 74 & 25.32 & 344.6 & $7 \%$ & 7 & 41 \\
\hline Mergosono & 0.74 & 74 & 1.00 & 1.0 & $100 \%$ & 100 & 87 \\
\hline Kotalama & 0.74 & 74 & 1.00 & 1.0 & $100 \%$ & 100 & 87 \\
\hline
\end{tabular}




\begin{tabular}{|l|l|l|l|l|l|l|l|}
\hline Kedungkandan & 0.81 & 81 & 27.84 & 142.7 & $20 \%$ & 20 & 50 \\
\hline Sawojajar & 0.74 & 74 & 1.00 & 1.0 & $100 \%$ & 100 & 87 \\
\hline Madyopuro & 0.96 & 96 & 0.00 & 160.0 & $0 \%$ & 0 & 48 \\
\hline Lesanpuro & 0.96 & 96 & 6.92 & 158.4 & $4 \%$ & 4 & 50 \\
\hline $\begin{array}{l}\text { Cemorokandan } \\
\text { g }\end{array}$ & 0.96 & 96 & 101.70 & 296.3 & $34 \%$ & 34 & 65 \\
\hline
\end{tabular}

*a: Domestic water use (Existing domestic water/domestic water demand b: WPI Value of Domestic water

c : Agriculture area (Ha)

$\mathrm{d}$ : Irrigation agriculture and non-irrigation agriculture

e : Use of agriculture

$\mathrm{f}:$ WPI Value of Agriculture

$\mathrm{g}$ : WPI Use (U)

The calculation of variable water use (U) value in Kedungkandang District has the same value between the poor and non-poor households. The poor and non-poor households are assumed to have the similar domestic and agricultural water value, because they live at the same area. Agricultural land use is obtained from the total area of agricultural land. There are limited data availability to calculate agricultural land because of less detailed map of land use in the level of sub-district. As result, there are only 3 sub-districts which categorized with low poverty level of the Use (U) component, since the rest of sub-district have value below the 68

\section{5) Environmental (E)}

The component of Environment (E) has 2 sub-components consist of vegetation cover and water quality. Vegetation cover is percentage of greenspace for each sub-district in the district. Measurement of water quality used the STORET method based on the Minister of Environment Decree No. 115 of 2003 concerning Guidelines for Determination of Water Quality Status. The value of water quality for each subdistrict is assessed from the quality of physical and non-physical water quality. The physical water quality has seen from three parameters - smell, taste and sediment. Whereas the nonphysical variables were carried out by laboratory tests with parameters of $\mathrm{PH}, \mathrm{DO}$, turbidity, electric conductivity and salt content. The results of the calculation of clean water quality in Kedungkandang District are categorized as being mildly polluted, thus it is given a WPI value of 75 .

\section{TABLE X. WATER POVERTY INDEX ENVIRONMENT}

\begin{tabular}{|l|l|l|l|l|}
\hline Subdistrict & $\begin{array}{l}\text { Water } \\
\text { quality }\end{array}$ & $\begin{array}{l}\text { \% } \\
\text { greenspace }\end{array}$ & $\begin{array}{l}\text { Greenspace } \\
\text { WPI value }\end{array}$ & $\begin{array}{l}\text { E WPI } \\
\text { value }\end{array}$ \\
\hline Arjowinangu & 75 & $65.15 \%$ & 65.15 & 70.1 \\
\hline Tlogowaru & 75 & $39.97 \%$ & 39.98 & 57.5 \\
\hline Wonokoyo & 75 & $15.63 \%$ & 15.63 & 45.3 \\
\hline Bumiayu & 75 & $60.34 \%$ & 60.35 & 67.7 \\
\hline Buring & 75 & $10.58 \%$ & 10.58 & 42.8 \\
\hline Mergosono & 75 & $11.46 \%$ & 11.47 & 43.2 \\
\hline Kotalama & 75 & $7.41 \%$ & 7.42 & 41.2 \\
\hline Kedungkandan & 75 & $16.98 \%$ & 16.98 & 46.0 \\
\hline Sawojajar & 75 & $11.42 \%$ & 11.42 & 43.2 \\
\hline Madyopuro & 75 & $14.27 \%$ & 14.28 & 44.6 \\
\hline Lesanpuro & 75 & $6.35 \%$ & 6.35 & 40.7 \\
\hline Cemorokandang & 75 & $10.30 \%$ & 10.30 & 42.7 \\
\hline
\end{tabular}

The environmental component implies an average value of water quality and vegetation cover. The value of water quality at each sub-district has similar value because water sample testing in all sub-district has a mildly polluted classification according to the Decree of the Minister of Environment No. 115 of 2003. Water samples are taken in the form of water sourced supplied by the PDAM, the HIPPAM and groundwater (individual - private wells). Whereas for calculating the value of vegetation cover presentation, it is obtained the area of green space (public + border + cemetery) from the basic map of Malang City Spatial Planning. Table X indicates that there is only one sub-district which has low poverty Environment index, namely Arjowinangun. Meanwhile, rest of the 11 sub-districts have poverty level from severe - medium low. Though, the data is limited, still this is a very important thing to be noticed since it might contribute bad value of the whole WPI value.

\section{6) Overall Value Of The Water Poverty Index}

Table XI indicates the total WPI value from the whole five components at each sub-district. There are only 2 sub-districts who have medium and medium low WPI value, sub-district of Mergosono and Sawojajar with value of 62.7 and 73.7, respectively. In conclusion, Kedungkandang District has a serious problem of poverty level, in the point of view access to water. So that, one strong recommendation to eradicate poverty level in Kedungkandang District that it is very important to focus upon improvement and development of access to water, particularly regarding component of use (U) and environment $(\mathrm{E})$, since they have good value of the other three components.

\section{TABLE XI. WATER POVERTY INDEX}

\begin{tabular}{|l|l|l|l|l|l|l|l|}
\hline Subdistrict & R & A & C & U & E & WPI & Classification \\
\hline Arjowinangu & 100 & 76.7 & 81.3 & 40.0 & 70.1 & 50.5 & High \\
\hline Tlogowaru & 100 & 77.2 & 84.3 & 61.1 & 57.5 & 55.3 & High \\
\hline Wonokoyo & 100 & 75.8 & 80.0 & 45.7 & 45.3 & 49.5 & High \\
\hline Bumiayu & 100 & 74.8 & 86.3 & 44.0 & 67.7 & 51.8 & High \\
\hline Buring & 100 & 78.7 & 86.8 & 40.7 & 42.8 & 49.7 & High \\
\hline Mergosono & 100 & 94.2 & 80.0 & 87.0 & 43.2 & 62.7 & Medium \\
\hline Kotalama & 100 & 78.9 & 82.0 & 87.0 & 41.2 & 60.3 & High \\
\hline Kedungkandan & 100 & 94.4 & 80.0 & 50.5 & 46.0 & 53.9 & High \\
\hline Sawojajar & 100 & 97.3 & 82.7 & 87.0 & 43.2 & 63.7 & Medium low \\
\hline Madyopuro & 100 & 78.4 & 81.3 & 48.1 & 44.6 & 50.7 & High \\
\hline Lesanpuro & 100 & 83.9 & 82.9 & 50.3 & 40.7 & 52.1 & High \\
\hline Cemorokandang & 100 & 66.7 & 81.3 & 40.0 & 70.1 & 52.8 & High \\
\hline
\end{tabular}

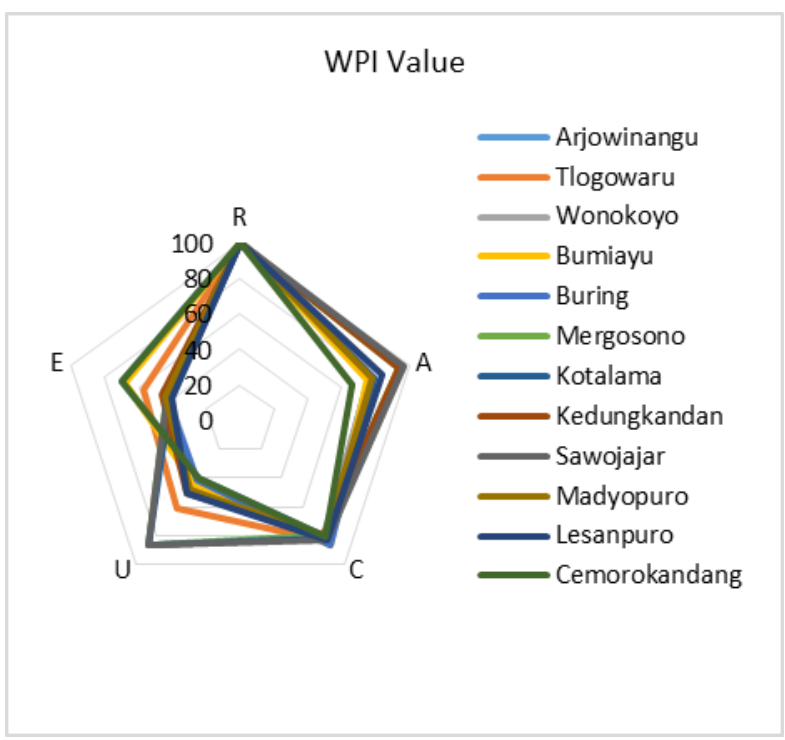

Fig.1 Radar Graph of the WPI Value

Figure 1 shows the compilation of each component in each sub-district. The two components of resource (R), and access (A) have a fairly good value amongst others, meanwhile the 
environment (E) has the lowest value. The WPI radar might also be used as a reference for government development strategy on how dealing with poverty alleviation which particular homework for each sub-district becomes very clear, as well as for the whole district.

\section{B. Social Network Analysts}

1) Rate of Participation (RoP)

The primary survey results show that Kedungkandang District has both informal and formal institutions. There are 5 formal institutions covering sub-district local government office, Integrated Healthcare Center (POSYANDU), Family Welfare Empowerment $(P K K)$, Sub-district Community Empowerment Agency $(L P M K)$ and cooperatives. Meanwhile, there also exist 3 informal institutions in the level of community consist of Male Islamic Recitation, female Islamic Recitation and Tahlil (Pray Together).

TABLE XII. PARTICIPATION RATE (ROP) - FORMAL INSTITUTIONS AFFILIATION OF THE WHOLE HOUSEHOLDS

\begin{tabular}{|c|c|c|c|}
\hline Subdistrict & $\begin{array}{c}\text { Number } \\
\text { of } \\
\text { institution }\end{array}$ & $\begin{array}{c}\text { RoP } \\
\text { formal }\end{array}$ & classification \\
\hline Arjowinangun & 6 & 1.45 & Low \\
\hline Bumiayu & 4 & 1.51 & Medium \\
\hline Buring & 4 & 1.24 & Low \\
\hline Cemorokandang & 6 & 1.5 & Low \\
\hline Kedungkandang & 5 & 1.49 & Low \\
\hline Kotalama & 4 & 1.68 & Medium \\
\hline Lesanpuro & 5 & 1.51 & Low \\
\hline Madyopuro & 4 & 1.25 & Low \\
\hline Mergosono & 5 & 1.79 & Medium \\
\hline Sawojajar & 4 & 1.77 & Medium \\
\hline Tlogowaru & 4 & 1.63 & Medium \\
\hline Wonokoyo & 4 & 1.19 & Low \\
\hline
\end{tabular}

TABLE XIII. PARTICIPATION RATE (ROP) - INFORMAL INSTITUTIONS AFFILIATION OF THE WHOLE HOUSEHOLDS

\begin{tabular}{|c|c|c|c|}
\hline Subdistrict & $\begin{array}{c}\text { Number of } \\
\text { institution }\end{array}$ & $\begin{array}{c}\text { RoP } \\
\text { informal }\end{array}$ & classification \\
\hline Arjowinangun & 3 & 1.18 & Medium \\
\hline Bumiayu & 3 & 1.58 & Medium \\
\hline Buring & 3 & 1.3 & Medium \\
\hline Cemorokandang & 3 & 1.67 & Medium \\
\hline Kedungkandang & 3 & 1.56 & Medium \\
\hline Kotalama & 3 & 1.72 & Medium \\
\hline Lesanpuro & 3 & 1.37 & Medium \\
\hline Madyopuro & 3 & 1.33 & Medium \\
\hline Mergosono & 3 & 1.69 & Medium \\
\hline Sawojajar & 2 & 1.83 & High \\
\hline Tlogowaru & 2 & 1.66 & High \\
\hline Wonokoyo & 2 & 1.08 & Medium \\
\hline
\end{tabular}

TABLE XIV. PARTICIPATION RATE (ROP) - FORMAL INSTITUTIONS AFFILIATION OF THE POOR HOUSEHOLDS

\begin{tabular}{|c|c|c|c|}
\hline Subdistrict & $\begin{array}{c}\text { Number } \\
\text { of } \\
\text { institution }\end{array}$ & $\begin{array}{c}\text { RoP } \\
\text { formal }\end{array}$ & classification \\
\hline Arjowinangun & 6 & 1.35 & Low \\
\hline Bumiayu & 4 & 1.36 & Medium \\
\hline Buring & 4 & 1.48 & Low \\
\hline Cemorokandang & 6 & 1.61 & Low \\
\hline Kedungkandang & 5 & 1.49 & Low \\
\hline Kotalama & 4 & 1.31 & Low \\
\hline Lesanpuro & 5 & 1.61 & Low \\
\hline Madyopuro & 4 & 1.26 & Low \\
\hline
\end{tabular}

\begin{tabular}{|c|l|l|l|}
\hline Mergosono & 5 & 1.82 & Medium \\
\hline Sawojajar & 4 & 1.53 & Medium \\
\hline Tlogowaru & 4 & 1.45 & Medium \\
\hline Wonokoyo & 4 & 1.34 & Medium \\
\hline
\end{tabular}

TABLE XV. PARTICIPATION RATE (ROP) - INFORMAL INSTITUTIONS AFFILIATION OF THE POOR HOUSEHOLDS

\begin{tabular}{|c|c|c|c|}
\hline Subdistrict & $\begin{array}{c}\text { Number } \\
\text { of } \\
\text { institution }\end{array}$ & $\begin{array}{c}\text { RoP } \\
\text { informal }\end{array}$ & classification \\
\hline Arjowinangun & 3 & 1.2 & Medium \\
\hline Bumiayu & 3 & 1.62 & Medium \\
\hline Buring & 3 & 1.21 & Medium \\
\hline Cemorokandang & 3 & 1.73 & Medium \\
\hline Kedungkandang & 3 & 1.62 & Medium \\
\hline Kotalama & 3 & 1.84 & Medium \\
\hline Lesanpuro & 3 & 1.4 & Medium \\
\hline Madyopuro & 3 & 1.21 & Medium \\
\hline Mergosono & 3 & 1.73 & Medium \\
\hline Sawojajar & 2 & 1.85 & High \\
\hline Tlogowaru & 2 & 1.71 & High \\
\hline Wonokoyo & 2 & 1.37 & Medium \\
\hline
\end{tabular}

TABLE XVI. PARTICIPATION RATE (ROP) - FORMAL INSTITUTIONS AFFILIATION OF THE NON-POOR HOUSEHOLDS

\begin{tabular}{|c|c|c|c|}
\hline Subdistrict & $\begin{array}{c}\text { Number } \\
\text { of } \\
\text { institution }\end{array}$ & $\begin{array}{c}\text { RoP } \\
\text { formal }\end{array}$ & classification \\
\hline Arjowinangun & 6 & 1.55 & Low \\
\hline Bumiayu & 4 & 1.65 & Medium \\
\hline Buring & 4 & 1.01 & Low \\
\hline Cemorokandang & 6 & 1.38 & Low \\
\hline Kedungkandang & 5 & 1.49 & Low \\
\hline Kotalama & 4 & 2 & Medium \\
\hline Lesanpuro & 5 & 1.42 & Low \\
\hline Madyopuro & 4 & 1.23 & Low \\
\hline Mergosono & 5 & 1.7 & Medium \\
\hline Sawojajar & 4 & 2.0 & Medium \\
\hline Tlogowaru & 4 & 1.81 & Medium \\
\hline Wonokoyo & 4 & 1.02 & Low \\
\hline
\end{tabular}

TABLE XVII. PARTICIPATION RATE (ROP) - INFORMAL INSTITUTIONS AFFILIATION OF THE NON-POOR HOUSEHOLDS

\begin{tabular}{|c|c|c|c|}
\hline Subdistrict & $\begin{array}{c}\text { Number of } \\
\text { institution }\end{array}$ & $\begin{array}{c}\text { RoP } \\
\text { informal }\end{array}$ & classification \\
\hline Arjowinangun & 3 & 1.13 & Medium \\
\hline Bumiayu & 3 & 1.54 & Medium \\
\hline Buring & 3 & 1.4 & Medium \\
\hline Cemorokandang & 3 & 1.6 & Medium \\
\hline Kedungkandang & 3 & 1.51 & Medium \\
\hline Kotalama & 3 & 1.6 & Medium \\
\hline Lesanpuro & 3 & 1.34 & Medium \\
\hline Madyopuro & 3 & 1.45 & Medium \\
\hline Mergosono & 3 & 1.65 & Medium \\
\hline Sawojajar & 2 & 1.80 & High \\
\hline Tlogowaru & 2 & 1.61 & High \\
\hline Wonokoyo & 2 & 0.79 & Medium \\
\hline
\end{tabular}

Table XII - XVII depict RoP at each sub-district that is classified into poor and non-poor households, as well as the combination for both type of households. Comparison result of the RoP at Table XII and XIII indicate that affiliation of the whole households into informal institution give higher level of participation. Though the number of formal institutions is higher than the informal institutions, but it seems that general community tends to join into a kind of informal institutions that is present in their neighborhood. Table XIV and XV illustrate that for the poor households participate in the 
informal institution is also quite common for them. It might refer that access to link to a kind of formal institution is quite rare or far for them. Similar result for the non-poor households also occur that is showed from Table XVI and XVII. Then, if we compare the RoP between the poor and non-poor households into formal institution in Table XIV and XVI, it indicates that the value is quite similar in the range between low and medium. Meaning that access to participate into formal institution for the whole type of households is quite far or not popular among the community. From Table XV and XVI similar pattern of the RoP between the poor and non-poor households is also found, though the value of RoP of the community to the informal institutions have higher value than to the formal one. In other words, informal institutions are more popular for the whole community regardless their economic background.

\section{2) Density}

Measurement of density in the community level might depict how dense relationship among of them within the subdistrict. The following Table XVIII and XIX depict the results of density divided into formal and informal institutions for the whole households, as well as the poor and non-poor households.

TABLE XVIII. DENSITY - INFORMAL INSTITUTIONS OF THE WHOLE HOUSEHOLDS

\begin{tabular}{|c|c|c|c|c|c|c|}
\hline \multirow{2}{*}{ Subdistrict } & \multicolumn{2}{|c|}{ informal Density value } & \multicolumn{3}{c|}{ Classification } \\
\cline { 2 - 7 } & $\begin{array}{c}\text { Anggre- } \\
\text { gate }\end{array}$ & Poor & $\begin{array}{c}\text { Non } \\
\text { poor }\end{array}$ & $\begin{array}{c}\text { Anggr- } \\
\text { egate }\end{array}$ & Poor & $\begin{array}{c}\text { Non } \\
\text { poor }\end{array}$ \\
\hline Arjowinangun & 0.48 & 0.43 & 0.45 & Medium & Medium & Medium \\
\hline Bumiayu & 0.42 & 0.45 & 0.46 & Medium & Medium & Medium \\
\hline Buring & 0.38 & 0.33 & 0.39 & Medium & Medium & Medium \\
\hline Cemorokandang & 0.41 & 0.41 & 0.39 & Medium & Medium & Medium \\
\hline Kedungkandang & 0.51 & 0.43 & 0.49 & Medium & Medium & Medium \\
\hline Kotalama & 0.50 & 0.45 & 0.49 & Medium & Medium & Medium \\
\hline Lesanpuro & 0.46 & 0.47 & 0.42 & Medium & Medium & Medium \\
\hline Madyopuro & 0,36 & 0,32 & 0,37 & Medium & Medium & Medium \\
\hline Mergosono & 0.62 & 0.59 & 0.63 & Medium & Medium & Medium \\
\hline Sawojajar & 0.79 & 0.71 & 0.72 & High & High & High \\
\hline Tlogowaru & 0.61 & 0.56 & 0.64 & Medium & Medium & Medium \\
\hline Wonokoyo & 0.43 & 0.46 & 0.47 & Medium & Medium & Medium \\
\hline
\end{tabular}

TABLE XIX. DENSITY - FORMAL INSTITUTIONS OF THE WHOLE HOUSEHOLDS

\begin{tabular}{|c|c|c|c|c|c|c|}
\hline \multirow{2}{*}{ Subdistrict } & \multicolumn{3}{|c|}{ Formal Density } & \multicolumn{3}{c|}{ Classification } \\
\cline { 2 - 7 } & $\begin{array}{c}\text { Anggre- } \\
\text { gate }\end{array}$ & Poor & $\begin{array}{c}\text { Non } \\
\text { poor }\end{array}$ & $\begin{array}{c}\text { Anggre- } \\
\text { gate }\end{array}$ & Poor & $\begin{array}{c}\text { Non } \\
\text { poor }\end{array}$ \\
\hline Arjowinangun & 0.50 & 0.50 & 0.50 & Medium & Medium & Medium \\
\hline Bumiayu & 0.70 & 0.65 & 0.69 & High & Medium & High \\
\hline Buring & 0.20 & 0.42 & 0.25 & Low & Medium & Low \\
\hline Cemorokandang & 0.60 & 0.54 & 0.60 & Medium & Medium & Medium \\
\hline Kedungkandang & 0.50 & 0.45 & 0.53 & Medium & Medium & Medium \\
\hline Kotalama & 0.60 & 0.64 & 0.56 & Medium & Medium & Medium \\
\hline Lesanpuro & 0.50 & 0.47 & 0.45 & Medium & Medium & Medium \\
\hline Madyopuro & 0.40 & 0.48 & 0.44 & Medium & Medium & Medium \\
\hline Mergosono & 0.70 & 0.65 & 0.75 & High & Medium & High \\
\hline Sawojajar & 0.80 & 0.72 & 0.77 & High & High & High \\
\hline Tlogowaru & 0.70 & 0.71 & 0.75 & High & High & High \\
\hline Wonokoyo & 0.30 & 0.42 & 0.35 & Low & Medium & Low \\
\hline
\end{tabular}

It is shown that the density in Kedungkandang District has value from low to high classification. Through their affiliation into informal institutions, it gives exactly similar value of density for the three categories - the whole households, the poor households, and the non-poor households, that mostly in the level of medium, and only one level of high - occurred in Sawojajar sub-district. The next table depicts that the non- poor households have more variety of density in the range from low - medium - high, meanwhile for the poor households, majority sub-districts have medium level, except two sub-district whit high value. If we compare value of the density between formal and formal institutions, it might conclude that relationships among community members is formed better through informal than formal institutions. The closer value to 1 or the higher value of density means that the relationships among households are very close to each other, and in the netdraw it might able to form almost a close connection to the whole part of the community within the subdistrict. In other words, informal institutions might have higher possibility to bring every community member into networks, so that in sense of flow of information or resources, connection among community members through information institutions might give more significant results than the other one.

\section{Spatial Modeling}

Spatial regression analysis functions to determine the spatial model between variables, as follows.

\section{Y: Water Poverty Index (WPI)}

\section{X1: Formal Rate of Participation}

\section{X2: Informal Rate of Participation}

\section{X3: Formal Density}

\section{X4: Informal density}

\section{X5: Travel time to Senior high school}

\section{X6: Travel time access to clean water}

1) Analysis of Moran's I and Local Indicator of Spatial Association (LISA)

Box plot is a summary of data using box diagrams or graphically to describe the shape of data distribution and illustrate the presence or absence of outliers (data with extreme values).

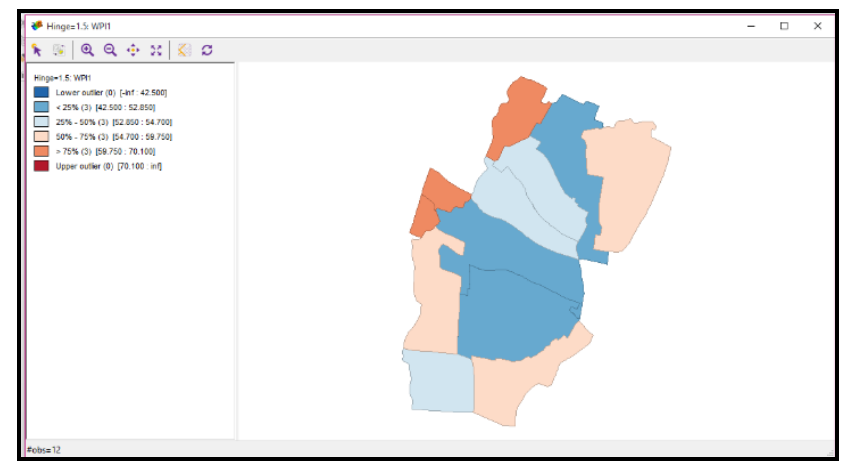

Fig. 2. Box Plo

In the Figure 2 there are no outliers estimated for the variables carried out by the WPI value for each sub-district for both lower and upper outliers.

\section{2) Spatial Weights}

Spatial weights are a representation of the inter-location linkages that make a difference for each of the surrounding locations. This spatial weight is created applying GeoDa software, with queen contiguity is to be chosen. The reason for using queen contiguity weights is because of the existence 
of areas that intersect with angles and sides in the study area, so that it will describe the best of the inter-location linkages.

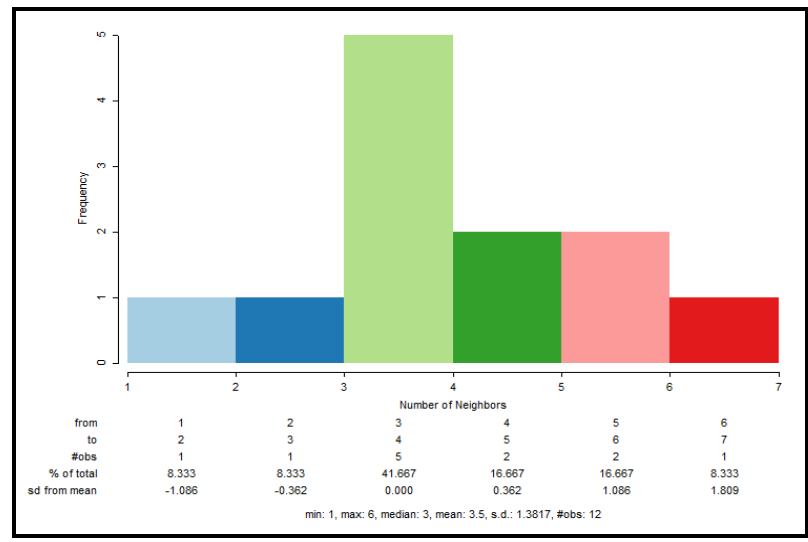

Fig.3. Connectivity Map

3) LISA Map

Lisa Map uses to identify neighborhood based on the proximity of the measured variable. Lisa Map illustrates the grouping of data based on the relationship between the WPI value and the influence of the nearest neighbor with the spatial weight of queen contiguity.

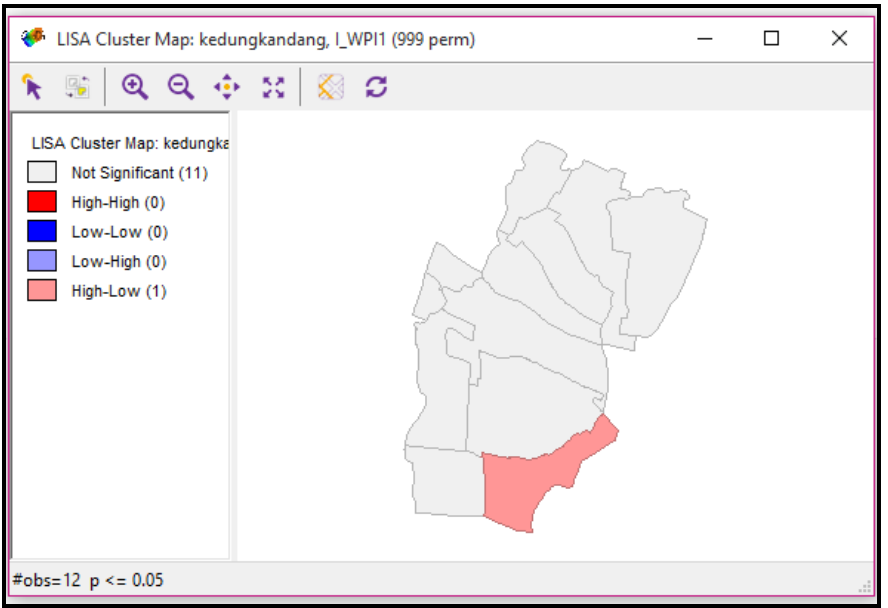

Fig. 4. LISA Map

\section{4) Spatial Regression}

Spatial modeling is analysis using a classical model for the first steps as another determinant of spatial analysis. This classic analysis determines the use of spatial lag or spatial error analysis to form a spatial model. In the first classic test, there are several variables that must be discarded because they do not have the significance test, such as travel time to senior high school and informal density. Then, for further analysis the value of formal rate of participation, informal rate of participation, density formal and access to water are analyzed.

TABLE XX.
\begin{tabular}{|l|l|l|l|l|}
\hline No & Variable & Coefficient & Probability & Hypothesis \\
\hline 1 & Constant & 13.41 & & \\
\hline 2 & $\begin{array}{l}\text { Trevel Time to } \\
\text { Access Water }\end{array}$ & -0.52 & 0.008 & Reject $\mathrm{H}_{0}$ \\
\hline 3 & RoP Informal & 22.77 & 0.0072 & Reject $\mathrm{H}_{0}$ \\
\hline 4 & RoP Formal & 35.27 & 0.0027 & Reject $\mathrm{H}_{0}$ \\
\hline 5 & Density Informal & 17.47 & 0.021 & Reject $\mathrm{H}_{0}$ \\
\hline 6 & Density Formal & -23.55 & 0.005 & Reject $\mathrm{H}_{0}$ \\
\hline 7 & $\begin{array}{l}\text { Travel time to } \\
\text { Senior High } \\
\text { School }\end{array}$ & 0.23 & 0.35 & Accept $\mathrm{H}_{0}$ \\
\hline
\end{tabular}

TABLE XXI.

Classic REgRESSION TEST Result 2

\begin{tabular}{|l|l|l|l|l|}
\hline No & Variable & Coefficient & Probability & Hypothesis \\
\hline 1 & Constant & 23.39 & & \\
\hline 2 & $\begin{array}{l}\text { Trevel Time to } \\
\text { Access Water }\end{array}$ & -0.52 & 0.006 & Reject $\mathrm{H}_{0}$ \\
\hline 3 & RoP Informal & 19.41 & 0.002 & Reject $\mathrm{H}_{0}$ \\
\hline 4 & RoP Formal & 33.67 & 0.001 & Reject $\mathrm{H}_{0}$ \\
\hline 5 & Density Informal & 14.808 & 0.017 & \\
\hline 6 & Density Formal & -22.135 & 0.003 & Reject $\mathrm{H}_{0}$ \\
\hline
\end{tabular}

TABLE XXII. SPATIAL DEPENDENCY DIAGNOSIS RESULTS

\begin{tabular}{|c|l|c|c|}
\hline No. & \multicolumn{1}{|c|}{ Coefficient } & Probability & Hypothesis \\
\hline 1. & Moran's I (error) & 0.72 & Accept $\mathrm{H}_{0}$ \\
\hline 2. & Lagrange Multiplier (Lag) & 0.21 & Accept $\mathrm{H}_{0}$ \\
\hline 3. & Robust LM (Lag) & 0.09 & Accept $\mathrm{H}_{0}$ \\
\hline 4. & Lagrange Multiplier (Error) & 0.47 & Accept $\mathrm{H}_{0}$ \\
\hline 5. & Robust LM (Error) & 0.19 & Accept $\mathrm{H}_{0}$ \\
\hline
\end{tabular}

This research run classic model 2 times (Table XX and Table XXI) until all variables have a significant value of probability $(<0.05)$. Table XX shows that time travel to senior high school has probability value 0.35 , hence for the next classic test there are only five variables can be calculated. Tables XXII shows that spatial dependency diagnosis result have five coefficients. All coefficients have no significant value. Meaning Hence, the final model that is formed for the research describes as follow.

$$
\begin{aligned}
& \hat{\mathrm{y}}=20.39+33.67 \mathrm{X}_{1}+19.41 \mathrm{X}_{2}-22.13 \mathrm{X}_{3}+14.81 \mathrm{X}_{4}-0.52 \mathrm{X}_{6} \\
& \mathrm{Y} \text { : Water Poverty Index } \\
& \mathrm{X}_{1} \text { : Formal Rate of Participation } \\
& \mathrm{X}_{2} \text { : Informal Rate of Participation } \\
& \mathrm{X}_{3} \text { : Formal Density } \\
& \mathrm{X}_{4} \text { : Informal density } \\
& \mathrm{X}_{6} \text { : Travel time access water }
\end{aligned}
$$

The regression model displays that formal rate of participation, informal rate of participation, formal density, informal density and travel time to access water variables affect the level of WPI. The rate of participation of both formal and informal institutions have positive value, meaning that higher the RoP of the community might form higher level of the WPI. Meanwhile, for coefficient of the density gives more interesting result, wherein in one hand, formal institutions give negative value to the WPI, and in the other hand, informal institutions give positive value of the WPI, similar to the RoP. It might assume that in order to develop community level, it is important to be able to control the negative effect of the formal institutions lower than the positive impact of the informal institutions. Then, the fifth significant independent variable is negative coefficient of the travel time to acquire clean water. This result is very clear, since the longer travel time to access water, the lower might occur to the WPI value. In other words, along with the SDGs target as well as the target of Indonesia Universal Access, it is very important to widen access to safe water through improved pipeline connection system. 


\section{CONCLUSION}

The WPI is a holistic method to measure poverty level through the five components, namely the availability of resources (R), access (A), capacity (C), use (U) and environment (E). It is suggested that in order to lower poverty level in Kedungkandang district there are at least two strategies need to be point out. Firstly, the two components of use (U) and environment (E) are important to be improved, wherein finding the best solution to solve conflict between water use for domestic and non-domestic needs. In addition, managing land use in best land use planning is also important to be tackle down, so that the rapid speed of the development might not give negative impact to the quantity and well as quality of the environment. Secondly, the note from the other three components is on how develop better strategy to increase access to safe water through widen pipeline water connection coverage service to reach the whole community at all distances.

The two indexes of the Social Network Analysis (SNA) rate of participation and density describe significant results on how community ties might give positive or negative impact to the development movement itself. Affiliation to both formal and informal presence institutions might give ability for both poor and non-poor households to be able to find better information or resources flow from both internal or even external sources of the community for their own betterment development. General suggestion might note that strengthening community ties through formal and informal institutions are necessary to established. Moreover, closer distance between formal institutions and the community member is important to be built in through better dissemination information as well resources within their formal program and activities based on the community-based participation

Interesting result occurs that both social and physical aspects give significant result to the effort on reducing poverty level in the community. Along with goal $6^{\text {th }}$ of the SDGs and national target of the Universal Access, improvement access to safe water for all through wider services of water pipeline connection is absolutely indispensable. Up most of it, role of social network among community members in order to have symmetry information as well as resources sharing from both internal and external of the community might give better result of the achievement of the poverty eradication targets as a whole [19].

\section{ACKNOWLEDGMENT}

This research is funded by Indonesia Ministry of Research, Technology and Higher Education. Sincere gratitude for the solid team - Anestia Lairatri. P, Bayu Seno Aji, Nadine Putri Wahyu, Nidyaul Elya

\section{REFERENCES}

[1] Nalle, Frederic W. Emilia K Kiha. 2018. Analisis Faktor-Faktor Yang Mempengaruhi Tingkat Kemiskinan di Kecamatan Insana Kabupaten Timor Tengah Utara (TTU). Ecological dynamics of development journal (I) : 3, pg 35-45

[2] Indonesian Ministry of National Development Planning. 2002 Kebijakan dan Strategi Penanggulangan Kemiskinan Perkotaan: Sebuah Gagasan. Jakarta

[3] Central Bureau of Statistic Malang City. 2019. Poverty depth index and poverty severity Index base on Regency/City in East Java 2015-2019

[4] Marganingrum,D, Heru Santoso, Didin Makhmuddin, Anna Fadilah Rusydi.2011. Kemiskinan dan Kemiskinan Air, Menuju Prioritas Aksi,Studi kasus: Cekungan Bandung. Bandung. LIPI Press, member of IKAPI.

[5] Anju, AM. SE Vicky. PJ Sajil Kumar. 2017. Water Poverty Analysis Using Water Poverty Index (WPI) - a Critical Review

[6] SDGs. (2015). SDGs Guide. Jakarta. http://www http://www.sdgsindonesia.or.id

[7] Ari, Ismu Rini Dwi. 2011. Dissertation: Participatory Approach to Community Based Water Supply System. Kyoto: Kyoto University Research Information Respository.

[8] Ari, Ismu Rini Dwi., Wijaya, I. N. S., Dewanto, A. 2018. Community Participation on Urban Sanitation Program: Comparison Study. IOP Conference Series Earth and Environmental Science 158(1):012013

[9] Ari, Ismu Rini Dwi. Budi Soegiarto Waloejo. Septiana Hariyani. Perspective of Social Capital into Poverty Level of the Community, Case Study Bumiaji District, Batu City, Indonesia. International Journal of Engineering Research 7 Technology. Vol 8. No 08,pp. 707714

[10] Ari, Ismu Rini et al. (2017) Infrastructure and Social Tie: Spatial model approach on understanding poverty in Malang regency, Indonesia. IOP Conf. Series: Earth and Environmental Science. Paper Open Access at IOP Conference Series: Earth and Environmental Science, 2017

[11] Local water distribution (PDAM). 2019. Service area statistics. http://www.pdamkotamalang.com/user/proses_menu/110 (diakses online pada 18 Desember 2019.

[12] Report on Implementation of poverty Alleviation in Malang City in 2018. Planning, Reseach and Development Agency Malang City

[13] Sullivan, C. A., et al. (2003) The Water Poverty Index: Development and Application at the Community Scale. Natural Resources Forum (189-199).

[14] Sullivan, C. A., Meigh, J. (2002) Calculating a Water Poverty Index Vol. 30 (7). London: Centre for Ecology \& Hydrology Wallingford, Oxfordshire.

[15] Sullivan, C. A., Meigh, J., Fediw, T. (2002) Derivation and Testing the Water Poverty Index Phase 1. London: Centre for Ecology \& Hydrology Wallingford, Oxfordshire.

[16] Khairuddin, Sunardi. Rachmat, Hariyanto.2014. Identifikasi Kondisi Kemiskinan Air Di Daerah Kabupaten Dompu, Provinsi Nusatenggara Barat.

[17] Guppy,L. (2014). "The Water Poverty Index in rural Cambodia and Viet Nam: A holistic snapshot to improve water management planning." Natural Resources Forum, 38, 203-219.

[18] Wasserman,Stanley \& Fraust,K.2009. Sosial Network Analysis: Methods and Applications.New York:Cambridge University.

[19] Putnam, R D, (2000) Bowling Alone: The Collapse and Revival of American Community. New York: 